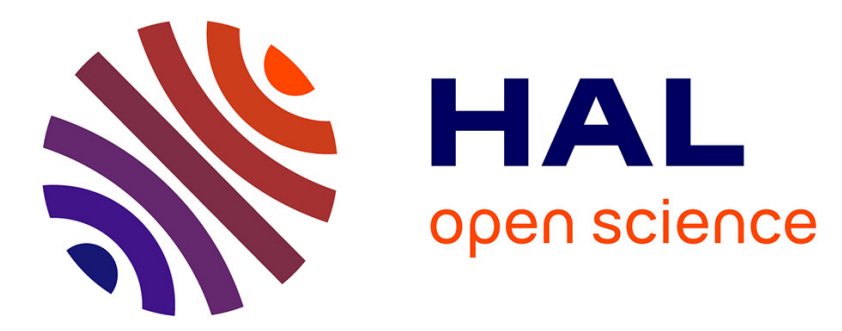

\title{
Isopod trackways from the Crayssac Lagerstätte, upper Jurassic, France
}

Christian Gaillard, Pierre Hantzpergue, Jean M.C. Vannier, Anne-Laurence Margérard, Jean-Michel Mazin

\section{To cite this version:}

Christian Gaillard, Pierre Hantzpergue, Jean M.C. Vannier, Anne-Laurence Margérard, Jean-Michel Mazin. Isopod trackways from the Crayssac Lagerstätte, upper Jurassic, France. Paleontology, 2004, 48 (5), pp.947-962. 10.1111/j.1475-4983.2005.00502.x . hal-00666942

\section{HAL Id: hal-00666942 \\ https://hal.science/hal-00666942}

Submitted on 6 Feb 2012

HAL is a multi-disciplinary open access archive for the deposit and dissemination of scientific research documents, whether they are published or not. The documents may come from teaching and research institutions in France or abroad, or from public or private research centers.
L'archive ouverte pluridisciplinaire HAL, est destinée au dépôt et à la diffusion de documents scientifiques de niveau recherche, publiés ou non, émanant des établissements d'enseignement et de recherche français ou étrangers, des laboratoires publics ou privés. 


\title{
ISOPOD TRACKWAYS FROM THE CRAYSSAC LAGERSTÄTTE, UPPER JURASSIC, FRANCE
}

\author{
by CHRISTIAN GAILLARD, PIERRE HANTZPERGUE, JEAN VANNIER, \\ ANNE-LAURENCE MARGERARD and JEAN-MICHEL MAZIN \\ UMR CNRS 5125 - Paléoenvironnements et Paléobiosphère, Université de Lyon 1, Géode - 2, rue Raphaël Dubois, F-69622 Villeurbanne Cedex, France; \\ e-mails: Christian.Gaillard@univ-lyon1.fr; Pierre.Hantzpergue@univ-lyon1.fr; Jean.Vannier@univ-lyon1.fr
}

Typescript received 26 November 2003; accepted in revised form 28 July 2004

\begin{abstract}
Well-preserved arthropod trackways are described from the laminated limestones of the Crayssac Lagerstätte (south-west France, Lower Tithonian). They occur in sediments deposited in the temporary coastal mudflats of intertidal to supratidal zones. The trackways are referred to Pterichnus isopodicus isp. nov., and are interpreted as the locomotion traces of isopods. Different trackway morphotypes are recognized and clearly resulted from variations in the original consistency of the sediment. Sinuous trackways may correspond to vagrant activity on wet mud whereas numerous straight ones indicate a more rapid crawling on a soft-to-firm substratum (e.g. tidal flat during emersion). The preferred orientation of trackways indicates that isopods
\end{abstract}

were crawling in a direction perpendicular to shoreline as a result of possible taxis induced by sediment wetness and/or by a migratory behaviour controlled by tidal rhythm. Unusually long emergence of the sediments may have favoured the preservation of dense networks of trackways. An isopod identity is supported by the general morphology of the tracks and the association of trackways with isopod body fossils. Archaeoniscus, which occurs abundantly in Late Jurassic deposits of England and France, was probably the trace-maker.

Key words: trackways, isopods, intertidal, Tithonian, southwest France.
The Upper Jurassic Crayssac Lagerstätte (Lot, south-west France) is famous for its exceptional assemblages of trace fossils that provide firm evidence of the traverse of intertidal mudflats by a variety of aquatic, terrestrial (crocodiles, dinosaurs, turtles) and even predominantly aerial vertebrates (pterosaurs) (Hantzpergue and Lafaurie 1994; Mazin et al. 1995, 1997, 2003). By contrast, the traces made by the invertebrate component of this biota have so far received scant attention from palaeontologists. We report here the first invertebrate trace fossils from Crayssac, trackways made by small arthropods. Their fine preservation, numerical abundance and well-documented environmental background all make Crayssac an exceptional locality for both ichnological and palaeoecological studies. We aim to give here a detailed description of the trackways, to explain their variability and toponomy, and to identify possible track-makers. We also analyse their ecological significance and their implications for the reconstruction of Mesozoic shallow-marine environments.

Arthropod trackways occur frequently throughout the fossil record but their relevance and palaeoecological significance are often misunderstood. Although some trackways can be easily attributed to well-documented arthropod groups such as trilobites (Seilacher 1955; Birkenmajer and Bruton 1971; Goldring 1985; Fortey and Seilacher 1997), limulids (Caster 1944; Nielsen 1949; Goldring and Seilacher 1971), myriapods (Briggs et al. 1979) and eurypterids (Braddy 1996; Draganits et al. 2001), the vast majority are difficult to assign. This is especially true for numerous small and relatively featureless trackways such as Isopodichnus. In some cases, the search for potential trace-makers in coeval deposits has proved successful. For example, Pollard (1985) related Isopodichnus in Triassic fluvial deposits to notostracans found in rocks of similar age. Similarly, Briggs and Almond (1994) realised the identity of arthropleurid trackways after arthropleurid body fossils were discovered in the same biota.

The main difficulty in interpreting arthropod trace fossils stems from the fact that diverse arthropod groups may produce similar trackways due to close morphological similarities in their walking legs. Moreover, environmental (i.e. wetness and consistency of sediment) and behavioural (i.e. locomotion speed) parameters greatly 
influence the trace-making process. In addition, the exact environmental setting under which the arthropod trackways were made is often unknown or imprecisely defined, relying on associated sedimentary structures. Trackways of small arthropods are known from continental to shallow-marine environments and are particularly abundant in Devonian-Triassic deposits (Brady 1947; Bandel 1967; Gevers et al. 1971; Trewin 1976; Briggs et al. 1979; Anderson 1981; Walter 1983; Pollard and Walker 1984; Walker 1985; Gordon 1988; Sadler 1993; Johnson et al. 1994; Bandel and Quinzio-Sinn 1999; Mangáno et al. 2002).

\section{MATERIAL AND METHODS}

The Crayssac Lagerstätte is situated $12 \mathrm{~km}$ north-west of Cahors (Lot, south-west France). The Lower Tithonian lithographic limestones known as the 'Pierre de Cahors' are well exposed in numerous quarries around the village of Crayssac. Between 1993 and 2001, the 'Mas de Pégourdy' quarry was intensively studied by scientists from the University of Poitiers and Lyon on a regular basis. The stratigraphical succession of the Lower Tithonian in this area was established by Hantzpergue and Lafaurie (1994) (Text-fig. 1). The limestones are about $100 \mathrm{~m}$ thick and subdivided into two formations, Salviac (Delfaud 1969) and Cazals, which is unconformably overlain by Cretaceous deposits (Cubaynes et al. 1989). Rare ammonites found in the basal part of the Cazals Formation indicate the Gravesiana Horizon of the Gigas Zone (Lower Tithonian). The Pierre de Cahors is therefore almost coeval with the Mörnsheimers Schichten of southern Germany and slightly older than the Solnhofen Plattenkalk which belongs to the Hybonotum Zone (Schweigert 1993).

The Tithonian deposits of Quercy (Aquitaine Basin) correspond to shallow-shelf restricted marine environments close to emergent areas (Central and Armorican land masses; see Thierry and Barrier 2000) (Text-fig. 2), with sequences culminating in tidalites (termed L1-L3). Numerous biosedimentary (cryptalgal laminites) and sedimentary features (ripple marks, mudcracks, raindrop marks) point to temporary lagoonal environments and/or coastal mudflats in the intertidal to supratidal zones. L3 has yielded an unusually rich and diverse ichnofauna with abundant vertebrate tracks including those of dinosaurs, crocodiles and pterosaurs preserved on the bedding planes of micritic laminated limestones (Mazin et al. 1997, 2003). The trace fossils are found associated with algae, pollen, bivalves, brachiopods, crustaceans, fish (complete individuals and scales) and isolated bones of crocodilians (Hantzpergue and Lafaurie 1994 and unpublished data).
In the Mas de Pegourdy quarry one particular limestone bed (c. $20 \mathrm{~mm}$ thick) is remarkable for the concentration of numerous trackways on three, discrete bedding planes (Text-fig. 1: Arthro 1-3). The trackways are relatively long, often exceeding $1 \mathrm{~m}$, and are best preserved in bed Arthro 2. This bed can be correlated with level $9 \cdot 73 \mathrm{~m}$ of the Solen 98 drill core (Courtinat et al. 2003). Repeated field observations have yielded detailed information concerning the general morphology, distribution and orientation of trackways preserved in Arthro 2. The best preserved material was photographed in situ and removed for further study. Silicone casts of large slabs and smaller key specimens were made in the quarry in order to obtain resin replicas for laboratory studies. Type specimens are housed in the collections of the Centre Commun de Collections de Géologie de l'Université Claude Bernard Lyon 1 (CG3), France, prefixed FSL.

\section{GENERAL DESCRIPTION AND ICHNOGENERIC ATTRIBUTION}

All of the trackways studied are preserved as epichnia (epichnial grooves/concave epirelief) according to the toponomic nomenclature of Martinsson (1970). As they represent locomotory traces, they are referred to the ethological category repichnia (see terminology of Seilacher 1953). These trackways form a criss-crossed network produced by several animals of the same species. Each trackway typically consists of two roughly parallel rows of small individual tracks all similar in size and shape (homopody), suggesting that the legs of the trace-maker were numerous and similar in size and shape. All these general characteristics point to arthropod trackways. Our descriptions follow the terminological scheme of Trewin (1994) subsequently modified by Braddy (2001).

Considerable confusion concerning the ichnotaxonomy of arthropod trackways has arisen partly due to preservational and behavioural factors that influenced the trace-making. Umfolozia from the Permian of South Africa is a perfect example of extreme variability controlled by these factors (Anderson 1981). That said, among the numerous arthropod trackways described in the literature, very few resemble those illustrated here from Crayssac. Oniscoidichnus is a probable isopod trackway but it is $10 \mathrm{~mm}$ wide and characterized by a low, sinuous median ridge and forward-pointing bractlike tracks on each side at intervals of about $1 \mathrm{~mm}$ (Brady 1949). This pattern differs from the Crayssac material. Superficial resemblances should also be noted with a few ichnotaxa listed in Text-figure 3. For example, Permichnium and Hamipes superficially resemble the trackways from Crayssac but the imprints have a double-scratch pattern not observed in the material from 


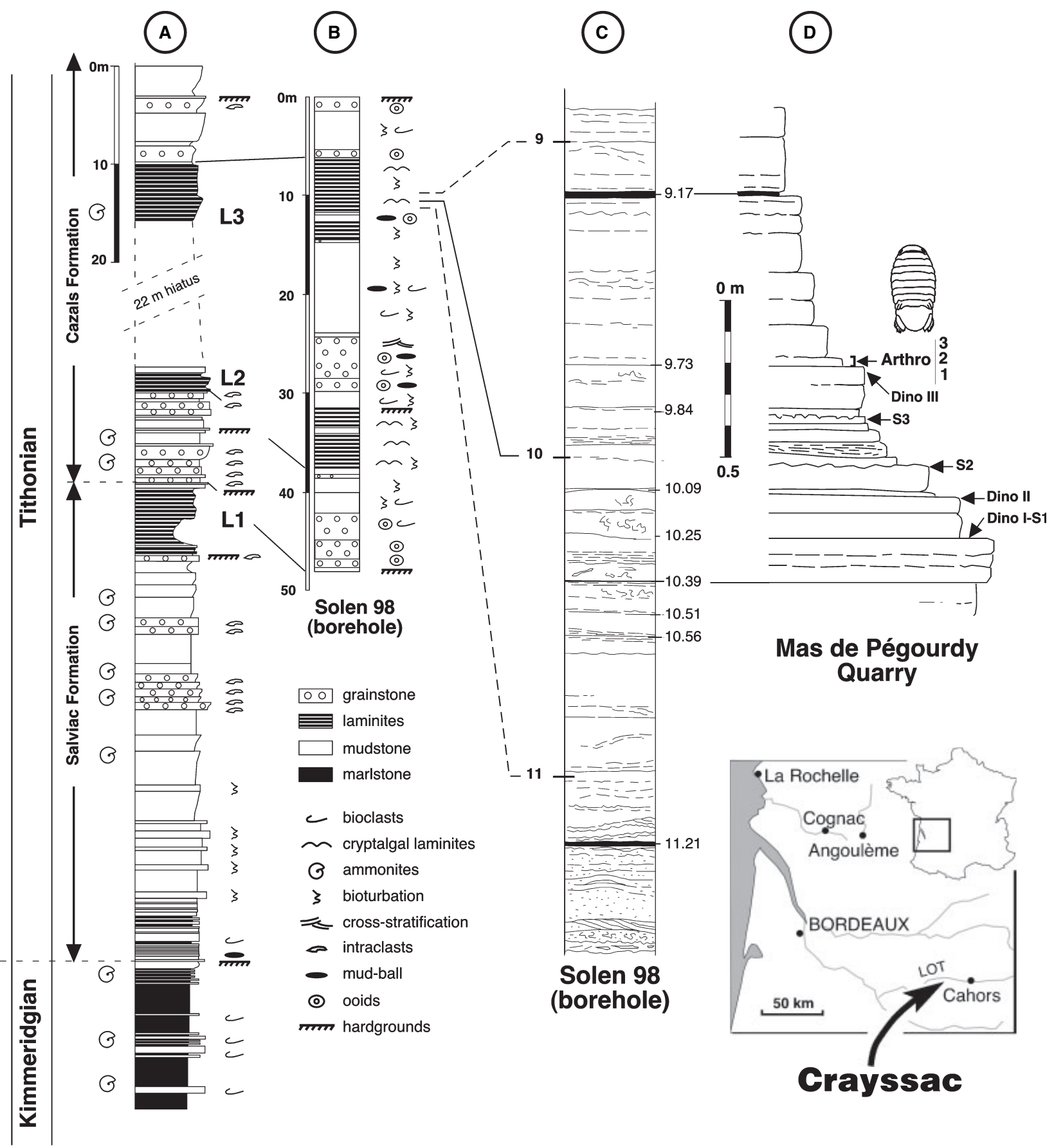

TEXT-FIG. 1. Lithology and stratigraphy of the Crayssac Fossil Lagerstätte. A, reconstructed lithological succession of the Upper Jurassic in the Quercy area (after Hantzpergue and Lafaurie 1994). B-C, Solen 98 drill core. D, occurrence of Pterichnus and other trackways in the Mas de Pégourdy quarry (Crayssac, Lot); Arthro 1-3, Pterichnus beds; Dino I-III, main surfaces with dinosaurs tracks.

Crayssac (Hitchcock 1858; Guthörl 1934). Paleohelcura (Gilmore 1926), Siskemia and Keircalia (Smith 1909) revised by Pollard and Walker (1984) and Walker (1985), also differ from our trackways in having one or several mid-axial drag marks.
Isopodichnus deserves special comment. It was erected by Bornemann (1889) and first revised by Schindewolf (1928) to accommodate Triassic specimens. Indeed Isopodichnus bears a confusing notation because the name implies the trace made by an isopod crustacean. It is 


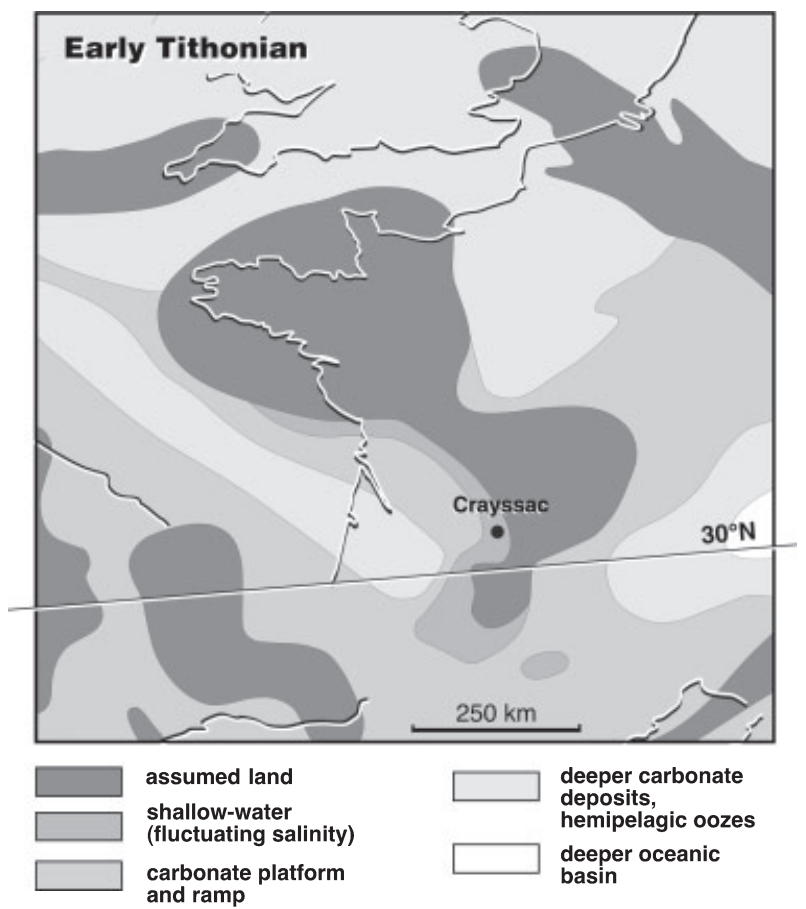

TEXT-FIG. 2. Palaeogeography of the area studied after Thierry and Barrier (2000), modified. characterized by a coffee-bean-shaped furrow or a doubleribbon trail striated by fine elongated scratches. Isopodichnus, Cruziana and Rusophycus are ill-defined ichnogenera that accommodate a wide variety of trails and resting traces, between which it is difficult to establish a sharp distinction. According to Trewin (1976), Isopodichnus may be distinguished by its smaller size. Moreover, its environmental significance is controversial although this ichnogenus is mainly considered as a good indicator of non-marine (Seilacher 1970), more precisely Mesozoic brackish-freshwater environments (Braddy 2001).

Diplichnites Dawson, 1873, with its type species D. oenig$m a$, is characterized by two rows of elongate tracks lying very close to each other and almost perpendicular to the axis of the trackway. This peculiar pattern does not occur in the trackways of Crayssac. Diplichnites may represent the walking traces of trilobites, with numerous morphotypes known from the Cambrian through to the Permian (Seilacher 1955; Crimes 1970) or, more probably, of myriapods (Briggs et al. 1979; Johnson et al. 1994). Similarly Ichnispica has long perpendicular tracks distributed in two parallel rows. Hitchcock $(1858,1865)$ described numerous trackways in the Triassic of Massachusetts, USA (Acanthichnus, Bifurculapes, Conopsoides, Hexapodichnus,

\begin{tabular}{|c|c|c|c|c|c|}
\hline TAXA & $\begin{array}{c}\text { average } \\
\text { width }\end{array}$ & APPENDAGE IMPRINTS & $\begin{array}{l}\text { drag } \\
\text { trails }\end{array}$ & \begin{tabular}{|c|} 
FREQUENT \\
OCCURRENCE
\end{tabular} & $\begin{array}{l}\text { GENERAL MORPHOLOGY } \\
\text { (after original description - not to scale) }\end{array}$ \\
\hline $\begin{array}{l}\text { Diplichnites } \\
\text { Dawson, } 1873\end{array}$ & $15 \mathrm{~mm}$ & $\begin{array}{l}\text { Two rows of close, short, } \\
\text { elongate, perpendicular } \\
\text { imprints }\end{array}$ & 0 & $\begin{array}{c}\text { Carboniferous } \\
\text { (Cambrian - } \\
\text { Permian) }\end{array}$ & | \\
\hline $\begin{array}{l}\text { Ichnyspica } \\
\text { Linck, } 1949\end{array}$ & $25 \mathrm{~mm}$ & $\begin{array}{l}\text { Two rows of long, elongate, } \\
\text { perpendicular imprints }\end{array}$ & 0 & Triassic & 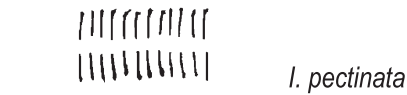 \\
\hline $\begin{array}{l}\text { Pterichnus } \\
\text { Hitchcock, } 1865\end{array}$ & $12 \mathrm{~mm}$ & $\begin{array}{l}\text { Two rows of long, elongate, } \\
\text { oblique }\left(15-20^{\circ}\right) \text { imprints }\end{array}$ & 0 & Triassic & 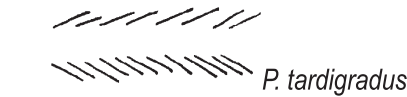 \\
\hline $\begin{array}{l}\text { Permichnium } \\
\text { Guthörl, } 1934\end{array}$ & $12 \mathrm{~mm}$ & $\begin{array}{l}\text { Two rows of V-shaped } \\
\text { imprints }\end{array}$ & 0 & Permian & $\begin{array}{l}\text { ルVVV } \\
\text { ハハハハ }\end{array}$ \\
\hline $\begin{array}{l}\text { Hamipes } \\
\text { Hitchcock, } 1858\end{array}$ & $40 \mathrm{~mm}$ & $\begin{array}{l}\text { Two rows of double inward- } \\
\text { curved imprints }\end{array}$ & 0 & Triassic & $\begin{array}{l}=ニ ネ \curvearrowright \\
=====H \text {. didactylus }\end{array}$ \\
\hline $\begin{array}{l}\text { Isopodichnus } \\
\text { Bornemann, } 1889\end{array}$ & $6 \mathrm{~mm}$ & $\begin{array}{l}\text { Small double-ribbon trail } \\
\text { transversely striated }\end{array}$ & $\begin{array}{c}\text { median } \\
\text { ridge }\end{array}$ & $\begin{array}{l}\text { Cambrian - } \\
\text { Triassic }\end{array}$ & 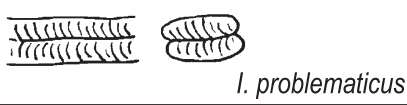 \\
\hline $\begin{array}{l}\text { Paleohelcura } \\
\text { Gilmore, } 1926\end{array}$ & $25 \mathrm{~mm}$ & $\begin{array}{l}\text { Two rows of oblique series } \\
\text { of three circular imprints }\end{array}$ & 1 & $\begin{array}{l}\text { Permian - } \\
\text { Triassic }\end{array}$ & 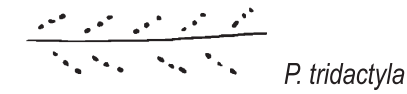 \\
\hline \multirow{2}{*}{$\begin{array}{l}\text { Siskemia } \\
\text { Smith, } 1909\end{array}$} & \multirow{2}{*}{$11 \mathrm{~mm}$} & \multirow{2}{*}{$\begin{array}{l}\text { Two parallel rows of } \\
\text { opposite series of } 2 \text { - } 4 \\
\text { imprints }\end{array}$} & \multirow{2}{*}{2} & \multirow{2}{*}{ Devonian } & $\therefore \quad: \quad \therefore \quad \therefore$ \\
\hline & & & & & $: \quad: \quad: \quad$ S. bipediculus \\
\hline $\begin{array}{l}\text { Keircalia } \\
\text { Smith, } 1909\end{array}$ & $13 \mathrm{~mm}$ & $\begin{array}{l}\text { Two parallel rows of very } \\
\text { closely spaced unclear } \\
\text { imprints }\end{array}$ & 4 & Devonian & 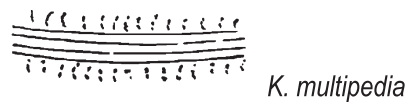 \\
\hline
\end{tabular}

TEXT-FIG. 3. Principal ichnotaxa corresponding to small arthropod trackways. 
Lithographus and Pterichnus), some being attributed to insects. Among them Pterichnus closely resembles the trackways of Crayssac because of its chevron-like pattern, and it is to this ichnogenus we refer our material.

\section{SYSTEMATIC ICHNOLOGY}

\author{
Ichnogenus PTERICHNUS Hitchcock, 1865
}

Diagnosis (after Häntzschel 1975, p. W99). 'Two rows of numerous [foot] imprints, turned outward from median line at angle of 15-20 degrees; width of trackway about $12 \mathrm{~mm}$, foot imprints $3 \mathrm{~mm}$ long.'

Discussion. Pterichnus was erected by Hitchcock (1865) for trace fossils in continental Triassic deposits from Massachussetts (USA). The specimens described in this publication were named Pterichnus centipes although they were previously assigned by the same author to Acanthichnus tardigradus (Hitchcock 1858). The definition of Acanthichnus ('track linear; in two parallel rows'; see Hitchcock 1858, p. 150) is not helpful. That of the type species of Acanthichnus is more informative: 'width of the two lines of tracks, 0.33 inch. Length of the tracks, 0.15 inch. Tracks turned outward from the median line, from $15^{\circ}$ to $20^{\circ}$. Distance between the successive tracks, $0 \cdot 1$ inch to $0 \cdot 25$ inch. Feet linear, acuminate; tracks opposite. Width of the trackway, 0.48 inch'. The reason why Hitchcock (1865, p. 14) changed the name is that the trace-maker was, according to him, a myriapod and not an insect. 'In my Ichnology, I have given a species of track under the name of Acanthichnus tardigradus, a small portion of which I copy in this paper on Plate VII, fig. 4; but which now seems to be more probably a Myriapod. I have therefore given it a new name. Pterichnus centipes (from pterou a feather, which the track resembles) taking it out of the genus Acanthichnus'. This makes the validity of P. centipes highly debatable. However, we follow Häntzschel (1975) who considered tardigradus as the type species of Pterichnus. The trackways from Crayssac fit within Pterichnus but their novel characteristics lead us to create a new ichnospecies.

Pterichnus isopodicus isp. nov. Text-figures 4-5

Derivation of name. From 'isopod', the assumed maker of the trackway.

Holotype. FSL 525001-1, Text-figures 4, 5A. Collections of the Centre Commun des Collections de Géologie C3G, University of Lyon 1.

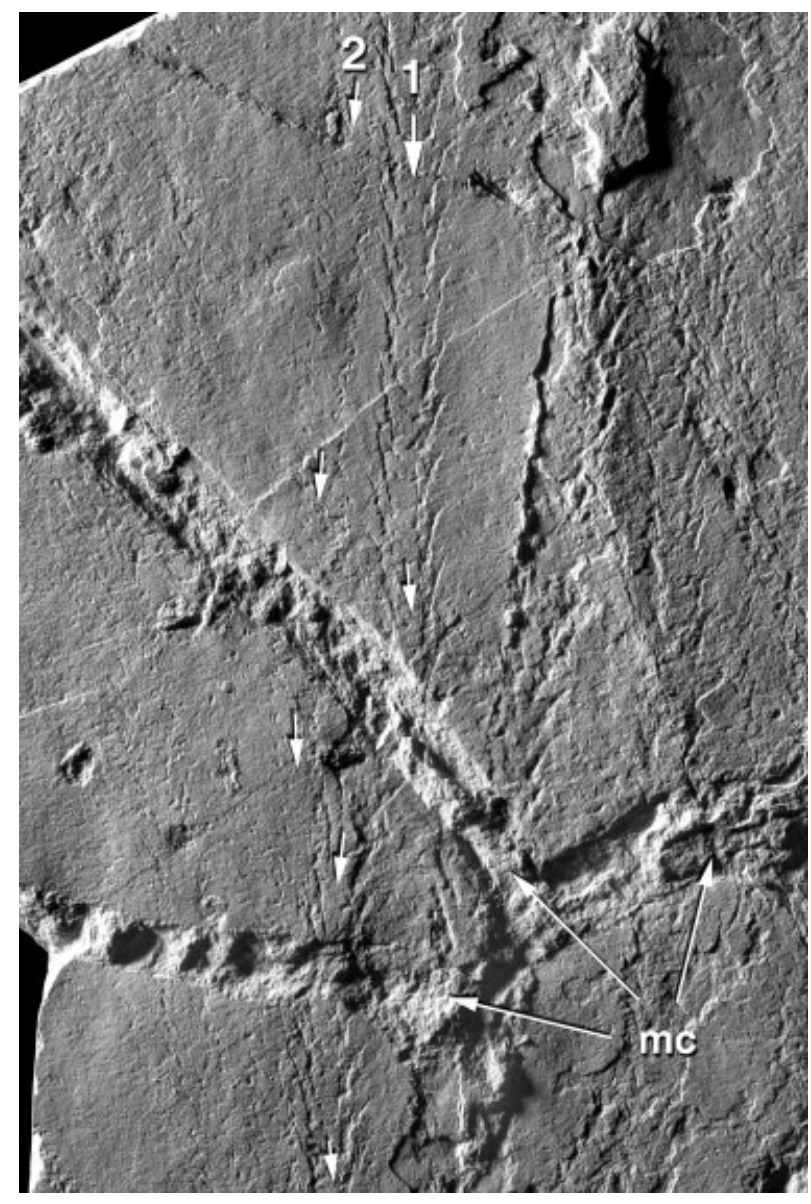

TEXT-FIG. 4. Pterichnus isopodicus isp. nov., Arthro 2 bed, Mas de Pégourdy quarry, Crayssac (Lot, France), Gigas Zone (lower Tithonian), FSL 525001, slab showing mudcracks intersecting trackways. White arrows indicate the assumed direction of movement of the trace-maker. 1, holotype FSL 525001-1; 2, paratype 1, FSL 525001-2; mc, mudcrack; $\times 1$.

Paratypes. Paratype 1, FSL 525001-2, Text-figure 5A; paratype 2, FSL 525002-1, Text-figure 5B; paratype 3, FSL 52002-2, Text-figure 5C. Collections of the Centre Commun des Collections de Géologie C3G, University of Lyon 1.

Type locality and horizon. Quarry 'Le Mas de Pegourdy' at Crayssac, Lot, France; Cazals Formation, Tithonian, Gigas Zone, laminated limestones, Arthro 2 bed (holotype in slab no. FSL 525001).

Diagnosis. Trackways with two symmetrical track rows; external width between 4 and $12 \mathrm{~mm}$ (average $7 \mathrm{~mm}$ ). Each row with repeated, elongate scratch-like tracks (up to $10 \mathrm{~mm}$ long; average $5 \mathrm{~mm}$ ) making an angle of 15-20 degrees with the midline (=trackway axis). Tracks have alternate symmetry. Internal or peripheral drag marks absent. 


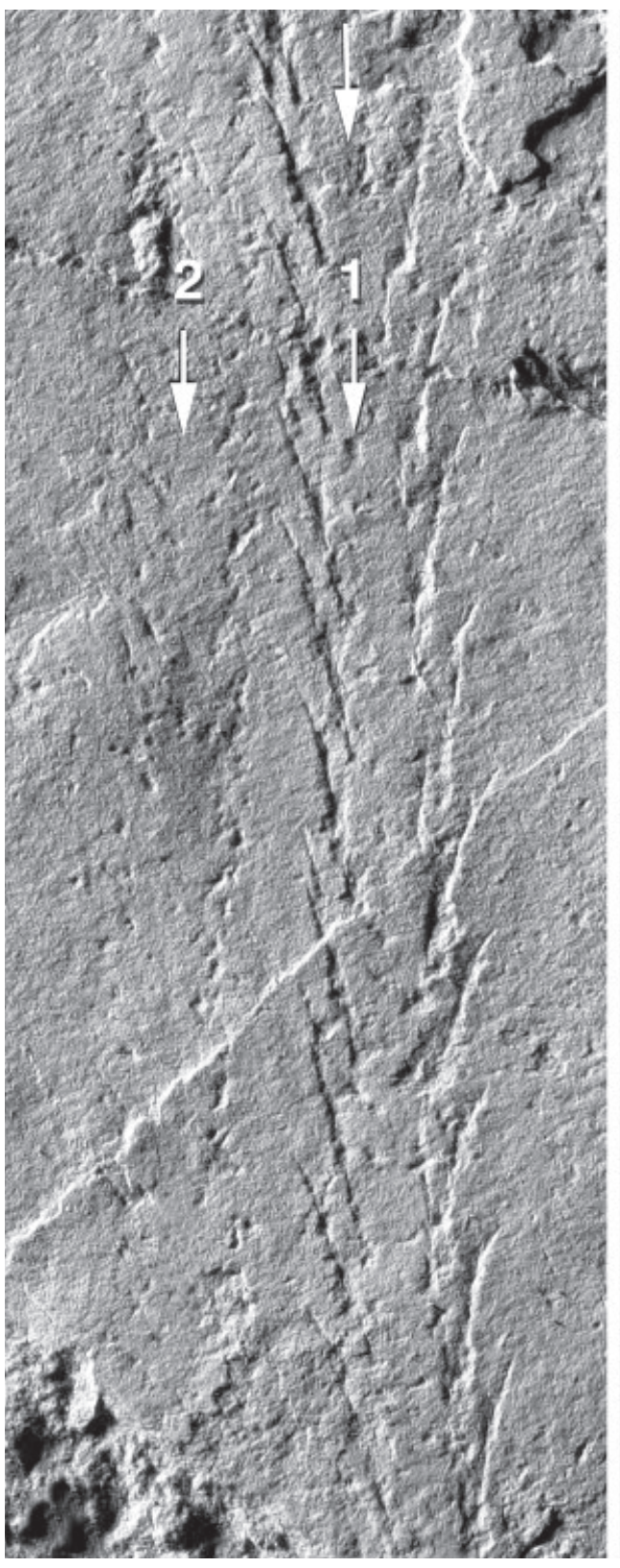

A

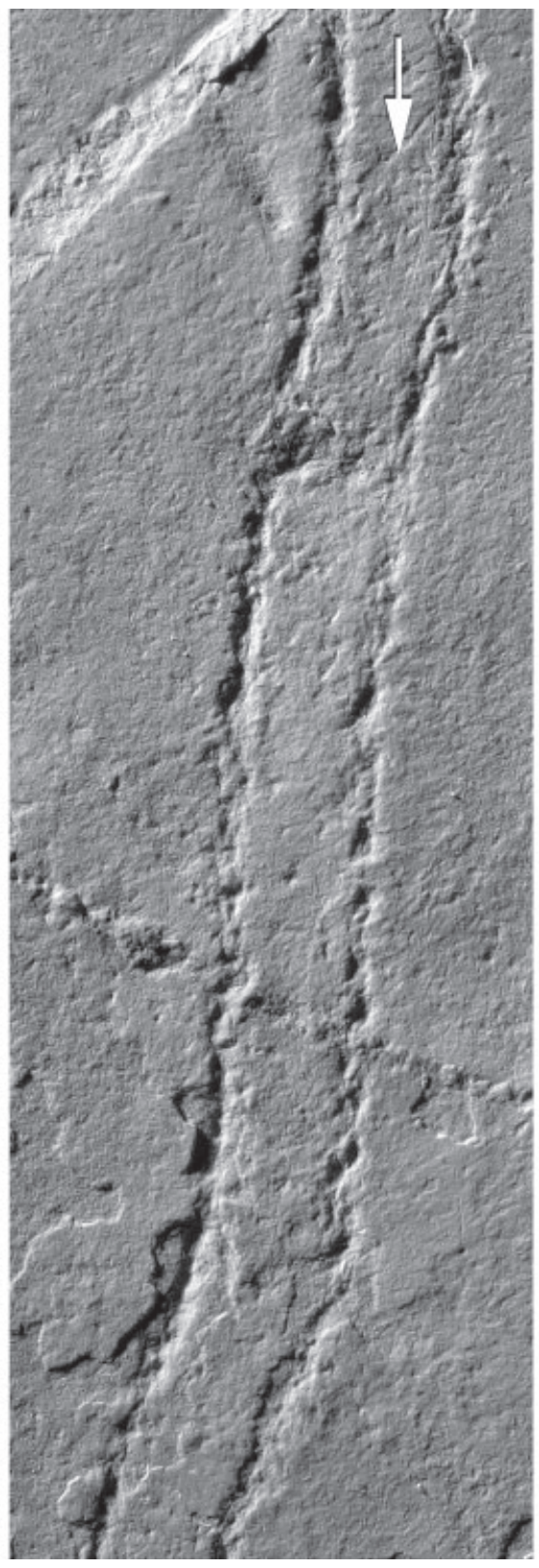

B

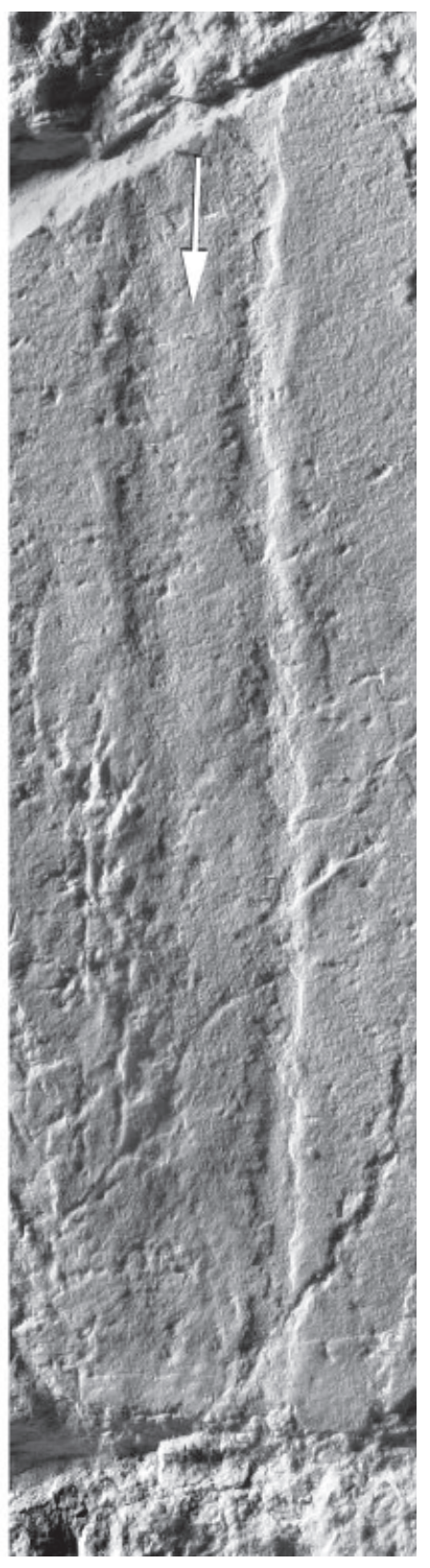

C

TEXT-FIG. 5. Pterichnus isopodicus isp. nov., same locality and age as in Text-fig. 4. A, FSL 525001: 1, holotype; 2 , paratype $1 ; \times 1 \cdot 5$. B, FSL 525002-1, paratype $2 ; \times 2$. C, FSL 525002-2, paratype $3 ; \times 2$. White arrows indicate the assumed direction of movement of the trace-maker.

Description. Eighty per cent of the trackways found at Crayssac possess the whole set of diagnostic features given in the diagnosis. However, variations occur and four different morphotypes (Types 1-4) can be recognized. Type 1 displays well-defined parallel rows but no scratch-like pattern (paratype 1, Text-fig. 5A). Type 2 corresponds to the holotype (Text-figs 4, 5A). In Type 3 the two rows consist of successive scratches lying almost parallel to the trackway axis and often connected to each other (paratype
2, Text-fig. 5B). It is unclear whether these markings were made by the appendages of the trace-maker or by the trailing edges of its exoskeleton (e.g. tips of pleurae). Type 4 is represented by a shallow depression with a flat bottom (paratype 3, Text-fig. 5C). It was probably made by the ventral part of the animal's body ploughing into the sediment. All intermediate morphotypes occur. The possible taphonomic origin of the trackway variability at Crayssac is discussed later. 
Remarks. Previously, P. tardigradus was the only ichnospecies assigned to Pterichnus. The trackways are wider in P. tardigradus $(12 \mathrm{~mm}$ ) than in P. isopodicus (average width, $7 \mathrm{~mm}$; maximum, $12 \mathrm{~mm}$ ). The individual tracks of P. tardigradus are opposite simple straight grooves whereas they are alternate and more complex in $P$. isopodicus. Another difference lies in the angle of imprints to the central axis of the trackway. It is relatively low in P. isopodicus (maximum 20 degrees) compared with P. tardigradus (15-20 degrees after the diagnosis, but up to 40 degrees according to the original drawing in Hitchcock 1858, pl. 28, text-fig. 1).

\section{AN IDENTITY FOR THE TRACE-MAKER}

\section{Evidence from the morphology of trackways}

Although isopod crustaceans may appear to be the possible makers of some fossil trackways, the literature provides no convincing evidence for this identity. Small unnamed trackways, in some aspects comparable to those from Crayssac, occur in the Upper Pennsylvanian estuarine sandstones of Kansas and have been tentatively attributed to isopods (Bandel 1967) and myriapods (Mangáno et al. 2002). Detailed comparisons between the putative isopod trackways and the actual locomotion trackways of Recent isopods may provide some clues. In this way, the ichnogenus Oniscoidichnus may be an isopod trackway because it resembles trackways of the Recent isopod Oniscus (Brady 1949). We carried out ichnological experiments in the laboratory using living isopods (both marine and terrestrial forms). Preliminary results indicate that the trackways produced by these isopods on mud superficially resemble those from Crayssac in their general aspect (Margérard 2000). However, detailed comparisons (e.g. grouping of leg imprints) between experimental and fossil traces remain difficult to establish.

\section{Fossil isopods associated with their trackways}

The co-occurrence of a trace fossil with the trace-maker is extremely rare. It has been illustrated, for example, by a few specimens of limulids from the Solnhofen Plattenkalk. These limulids are found in situ lying at the end of their trackway (Goldring and Seilacher 1971; Barthel et al. 1990). Such trace fossils are convincingly interpreted as death trackways and are markedly different from the regular locomotion trackways produced by limulids, both Recent and fossil. A comparable association of a trail and a body fossil also occurs in the laminated limestones of Crayssac, as exemplified by one specimen from Arthro 3. The trail in question is $12 \mathrm{~mm}$ wide and consists of a very shallow groove with neither visible individual footprints nor scratches (Text-fig. 6). It falls within the trackway morphotype defined earlier as Type 4 and shows a conspicuous oval body at one end, bearing traces of trunk segmentation, hemispherical extremities and the possible remains of antennae. Although poorly preserved, this body resembles that of an isopod crustacean. Similarly with the limulids from Solnhofen, the abrupt termination of the trackway and the orientation of the trace-maker suggest that the assumed isopod died at the end of its trackway.

\section{Upper Jurassic isopods}

Isopods are relatively abundant and diverse in Upper Jurassic fine-grained limestones. For example, four different species, namely Palaega kunthi (Ammon, 1882), Urda rostrata Münster, 1840, and Urda punctata Münster, 1842

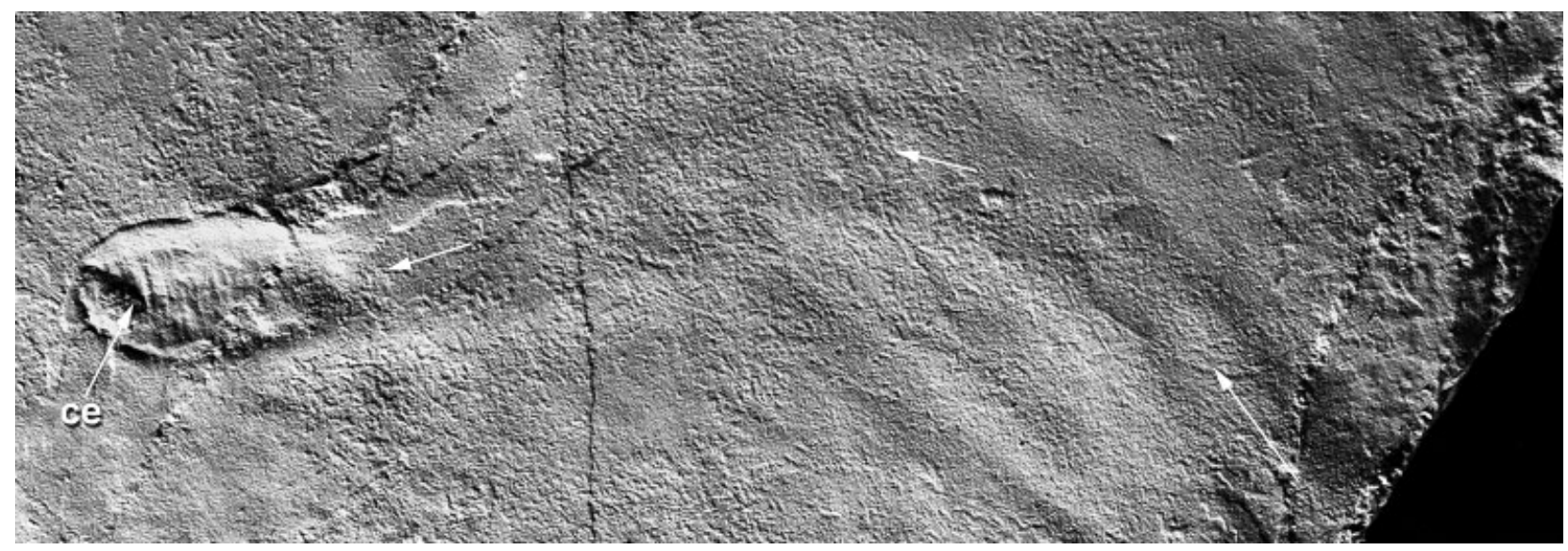

TEXT-FIG. 6. Assumed death trackway produced by Archaeoniscus sp., Arthro 3 bed, Mas de Pégourdy quarry, FSL 525004. ce, cephalic part of the isopod; white arrows indicate the direction of movement of the trace-maker; $\times 2 \cdot 3$. 


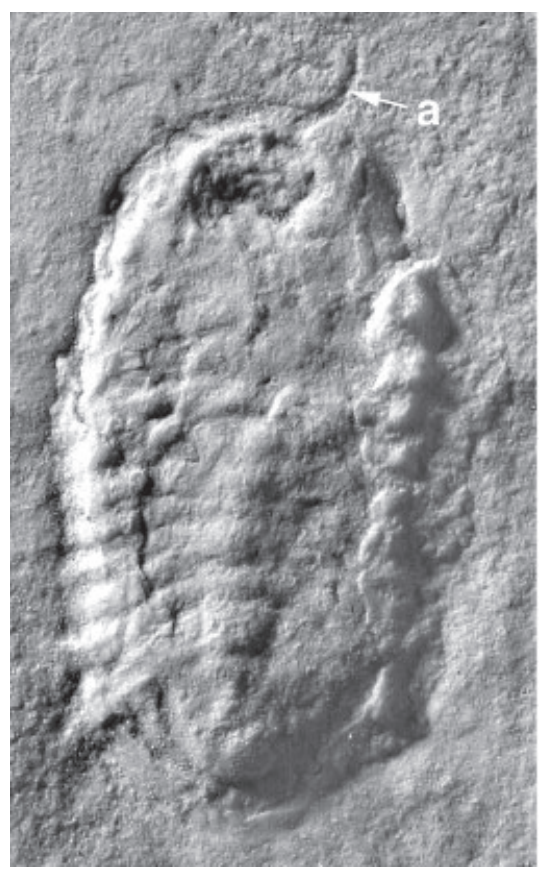

A

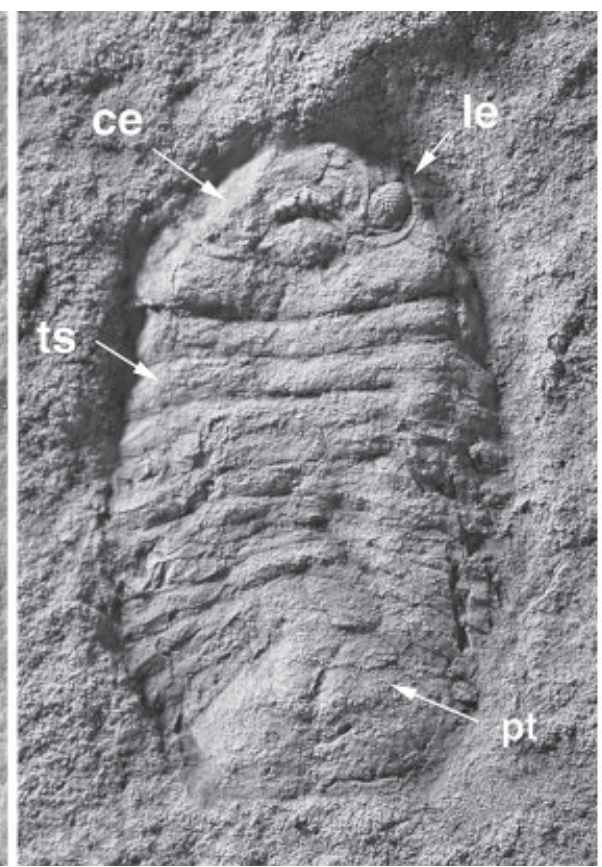

B

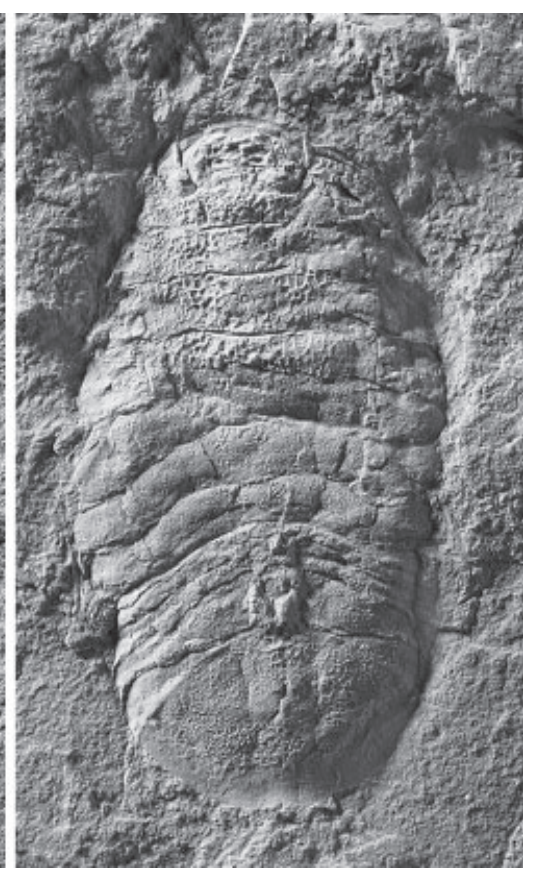

C

TEXT-FIG. 7. A, Archaeoniscus sp., Arthro 2 bed, Mas de Pégourdy quarry, Coll. G. Lafaurie, FSL 525007; ×5. B, Archaeoniscus sp., Brénod (Ain, France), uppermost Kimmeridgian, Coll. C. Gourrat, FSL 525008; × 10. C, Archaeoniscus brodiei Milne-Edwards, 1843, NHM I 3024b, Dinton, Vale of Wardour, Wiltshire, England, Durlston Formation, Purbeck Group, Berriasian; $\times 2 \cdot 5$. a, antenna; ce, cephalon; le, lateral eye; pt, pleotelson; ts, thoracic segment.

(Frickhinger 1994; Van Straelen 1928), and the exquisitely preserved Schweglerella strobli Polz, 1998 (Polz 1998; Brandt et al. 1999) occur in the Early Tithonian Solnhofen Plattenkalk of southern Germany. Isopods are also present in the Upper Jurassic lithographic limestones of Cerin (Ain, south-east France; unpublished data). Archaeoniscus brodiei Milne-Edwards, 1843 has long been known from the uppermost Tithonian-Berriasian Purbeck Limestone Group of Wiltshire and Dorset, southern England (see complete references in Ross and Vannier 2002) (Text-fig. 7C) and from coeval deposits in Germany (e.g. Serpulite of Hagen: Haack 1918; Van Straelen 1928). A congeneric undescribed species with close affinities to A. brodiei also occurs abundantly in the Upper Kimmeridgian fine-grained limestones at Brénod (Jura Mountains, Ain, France) (Text-fig. 7B). Two other species of Archaeoniscus have been described from the Upper Cretaceous of Texas (Wieder and Feldmann 1992) and the Albian of Mexico (Feldmann et al. 1998). A. brodiei is an oval and moderately vaulted isopod with its frontal part entirely occupied by a kidney-shaped unit (cephalon + first pereionite). The rest of its exoskeleton consists of a uniform series of seven pereionites and terminates at a hemispherical pleotelson.

The isopods found at Crayssac are extremely rare and poorly preserved. The best individual most probably belongs to Archaeoniscus and resembles A. brodiei from the Purbeck of England (Text-fig. 7A). However, its specific assignment within Archaeoniscus remains uncertain because of the scarcity and poor preservation of the material. One particular bedding plane from the Mas de Pégourdy quarry is, in places, crowded by imprints of isopods (Text-fig. 8). Although poorly preserved, most of these specimens have isopod characters such as a reniform cephalon with lateral eyes, a series of trunk somites, a hemispherical pleotelson and associated scratches possibly left by appendages. Whether these small specimens belong to Archaeoniscus is uncertain.

The taphonomy of this peculiar bedding plane is noteworthy as the isopods are orientated in the same direction. This assemblage may be the result of the transportation and deposition of dead isopods or exuviae by, for instance, tidal currents. If so, the preferential orientation of dead animals would result from current action. An alternative hypothesis is that these imprints are the resting traces of isopods which lived on this surface. They are not associated with trackways and could indicate a precise behaviour in the presence of bottom currents. Isopods possibly rested on the bottom, aligned themselves to the current and slightly burrowed into the mud to avoid drifting away. We have no examples of such behaviour in the Recent, but Weber and Braddy (2004) have noted a similar situation for Selenichnites in Ordovician tidal deposits in Antarctica. 


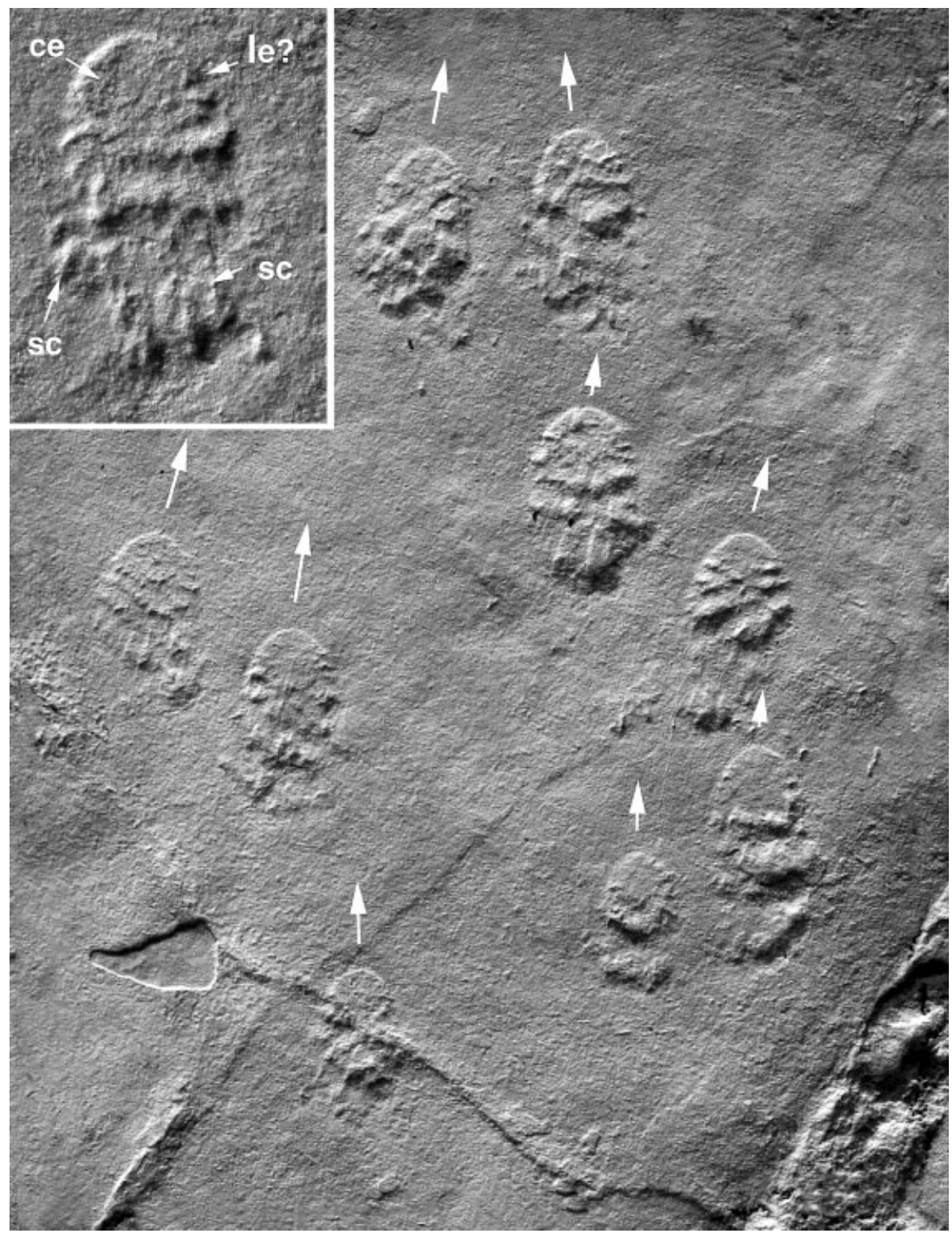

TEXT-FIG. 8. Surface of bedding plane crowded with isopods (either post-mortem re-orientation of dead animals by currents or resting traces of living animals aligned to the current; see white arrows), Mas de Pégourdy quarry, FSL 525006. ce, cephalon; le?, lateral eye?; sc, possible scratch marks made by walking legs; main photograph; $\times 4$, small photograph; $\times 7$.

Additional supporting evidence for Archaeoniscus as the possible trace-maker of Pterichnus isopodicus comes from measurements and more precisely from direct comparisons between the width of trackways and the width of the associated isopod fossils (Text-fig. 9). Some 128 well-preserved trackways (Arthro 2) and 113 isopods from Crayssac were measured. Width measurements of Archaeoniscus sp. from Brénod were also used for additional comparisons. The width of isopods from both Crayssac and Brénod falls within the external width range of trackways from Crayssac. However, the vast majority of isopods from Crayssac are relatively small $(2-5 \mathrm{~mm})$ and do not correspond to the most frequent trackway width $(87$ per cent between 5 and $10 \mathrm{~mm}$ ). The same is true for the isopod assemblage from Brénod. This discrepancy may be explained by the fact that juvenile isopods were not living in the same environment as adults or were simply not heavy enough to leave traces on the sediment. The small isopods from Crayssac (see Text-fig. 8) seem to have been transported and sorted by currents and do not show a normal size distribution. According to the second hypothesis (resting traces of living isopods), mainly isopods of the same age interval could have presented the peculiar behaviour previously proposed. 

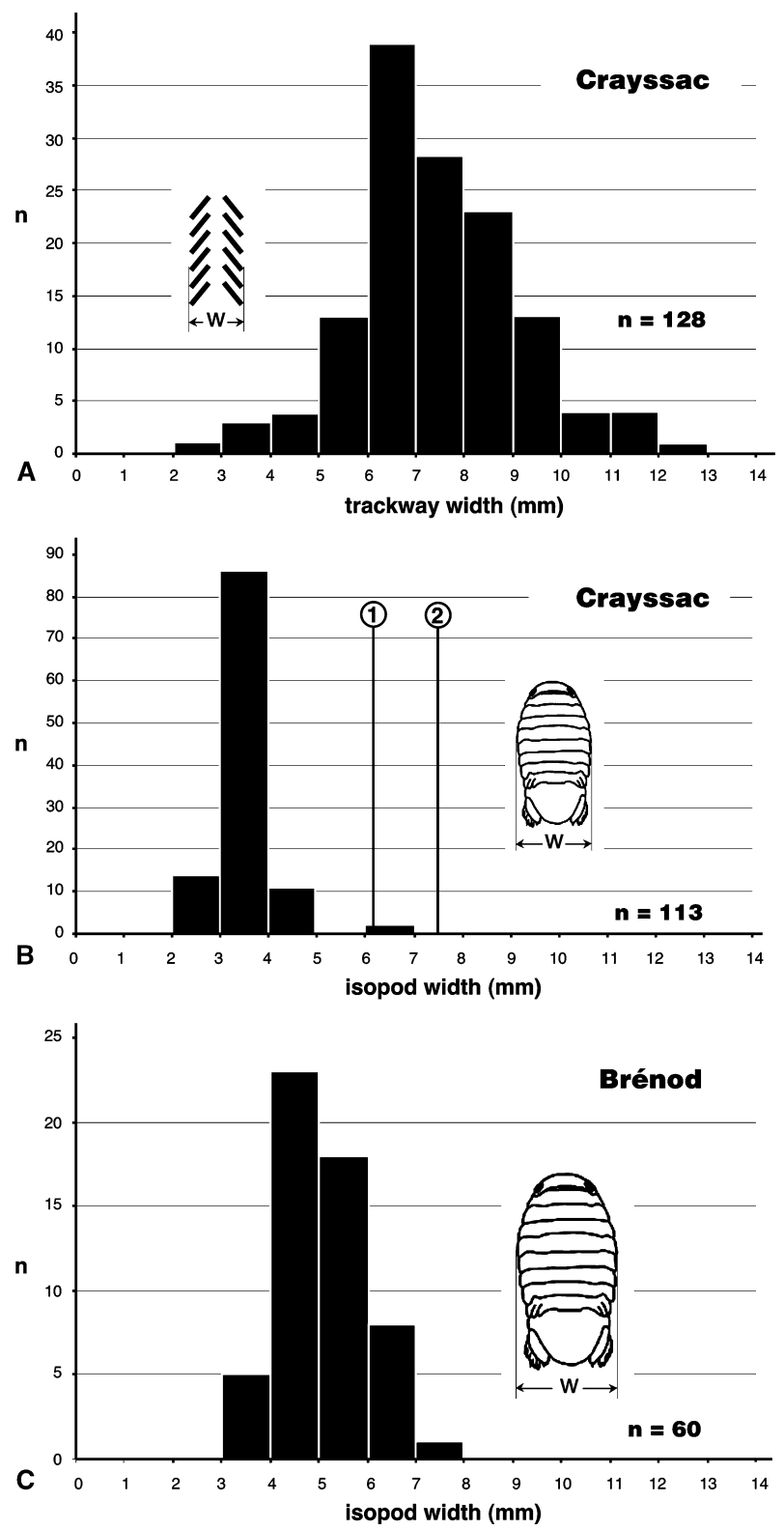

TEXT-FIG. 9. Width distribution of trackways and probable related isopods. A, Pterichnus isopodicus isp. nov. from Crayssac. B, Archaeoniscus sp. from Crayssac, all from FSL 525006 (see Text-fig. 8) except 1, FSL 525004 (see Text-fig. 6) and 2, FSL 525007 (see Text-fig. 7A). C, Archaeoniscus sp. from Brénod.

\section{ENVIRONMENTAL AND ECOLOGICAL SIGNIFICANCE}

\section{The Crayssac environment}

The Lower Tithonian deposits of Crayssac are nearshore shallow-water carbonates among which six main lithofacies (from grainstone to mudstone) are recognized, indicating diverse environmental conditions from very proximal (tidal flats; possibly brackish environments) to more distal (oolitic shoals) (Courtinat et al. 2003). The occurrence of marine (algae, bivalves, brachiopods, crustaceans, fish) and terrestrial (reptiles, plants) organisms are good indicators of the vicinity of land and marine influence (Hantzpergue and Lafaurie 1994; Mazin et al. 1995, 1997). The isopod trackways occur in laminated limestones deposited in the most proximal facies, i.e. of a probable intertidal mudflat, as attested to by tidal laminations, algal mats, mudcracks and raindrop marks. The presence of dense networks of superimposed isopod trackways associated with vertebrate footprints (e.g. pterosaurs) on the surface of mudcracked bedding planes suggest that animal activity occurred over temporary emergent areas.

The morphological variability of arthropod trackways is closely related to physical factors such as the consistency and wetness of sediment (Johnson et al. 1994; Trewin 1994). The Crayssac trackways are likely to have been imprinted in the soft-to-firm mud of a temporarily emerged tidal flat. The chronology of traversal of these wet areas by isopods can be reconstructed by examining the cross-cutting relationship of the trackways. Type 4 trackways were produced first and indicate animal activity on a substratum saturated with water. They were followed successively by Type 3, Type 2 (well-defined tracks; humid conditions) and eventually Type 1 (early desiccation) (Text-fig. 10). In the final stage, the mud dried up and the whole network of trackways was fragmented by mudcracks. Microbial mats probably played an important role in the preservation of trackways (stabilization of sediment after the formation of trackways). This is well

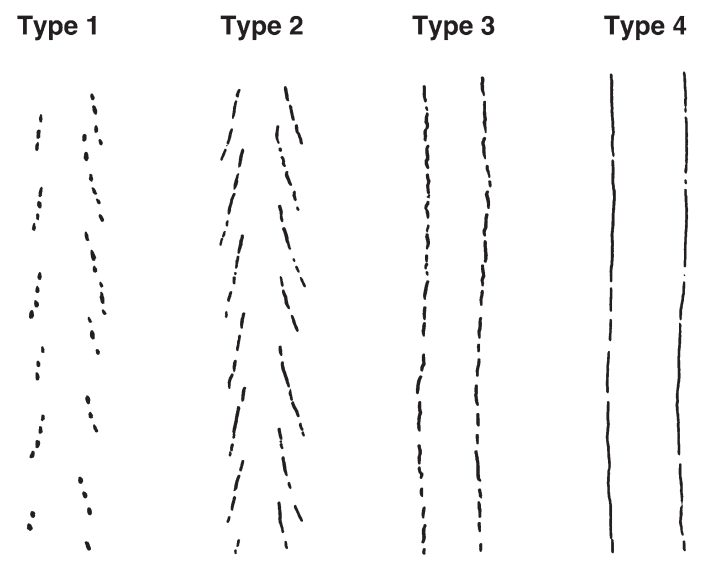

TEXT-FIG. 10. Relation between the morphology of Pterichnus isopodicus isp. nov. and the consistency of the sediment (see Text-fig. 5 and description of Types 1-4 in text). 
demonstrated in Upper Jurassic deposits similar to those of Crayssac (Gall et al. 1985; Gaillard et al. 2003) and, possibly, in sediments representing other environments in which arthropod trackways are preserved (Draganits et al. 2001).

\section{Ecology of Crayssac isopods}

The unusual density of isopod trackways at Crayssac raises important questions concerning the ecological niche and lifestyle of these animals and their role in the intertidal ecosystem. Were tidal flats the preferred and permanent habitat of the isopods or simply a temporary migration area? Were the isopods marine or supratidal crustaceans?

Morphology of trackways. Trackway Types 3 and 4 were made on the surface of wet sediment whereas Types 1 and 2 result from locomotory activities in much drier conditions (Text-fig. 10). The variety of trackway types suggests that the track-maker crawled on both damp (possibly submerged by a film of water) and dry muddy substrates. The trajectory of the trackways is also very informative. It is straight in Types 1 and 2 and typically sinuous in Types 3 and 4 (Text-fig. 11). Ichnologists usually consider straight trajectories as reliable indicators of locomotion (repichnia). At Crayssac, the unidirectional and probable rapid crawling of isopods (trackways of Types 1 and 2) may have resulted from a taxis induced by sediment wetness, daylight or topographic gradient. More sinuous trackways (Types 3 and 4) would merely correspond to vagrant activities possibly connected with the search for food (pascichnia). Similar interpretations have been proposed for sinuous trilobite trackways (Seilacher 1970). Because Types 3 and 4 (pascichnia) usually precede Types 1 and 2 (repichnia) in the succession of trackways (see above), one may envisage that the isopods had vagrant activities related to feeding and were migrating in response to the desiccation of the substratum. Rare trackways that end abruptly and terminate as a burrowing-like trace suggest that isopods could dig into the top few millimetres or centimetres of sediment (Text-fig. 12). Such burrowing behaviour occurs in Recent isopods such as Eurydice (Jones and Naylor 1970), Paragnatia and Limnoria (Roman and Dalens 1999).

Abundance and direction of trackways. The abundance of the trackways is high, reaching approximately 150 per $\mathrm{m}^{2}$ on the surface of the Arthro 2 horizon. This density suggests that the traces were made within the area inhabited by the isopod populations. The orientation of numerous
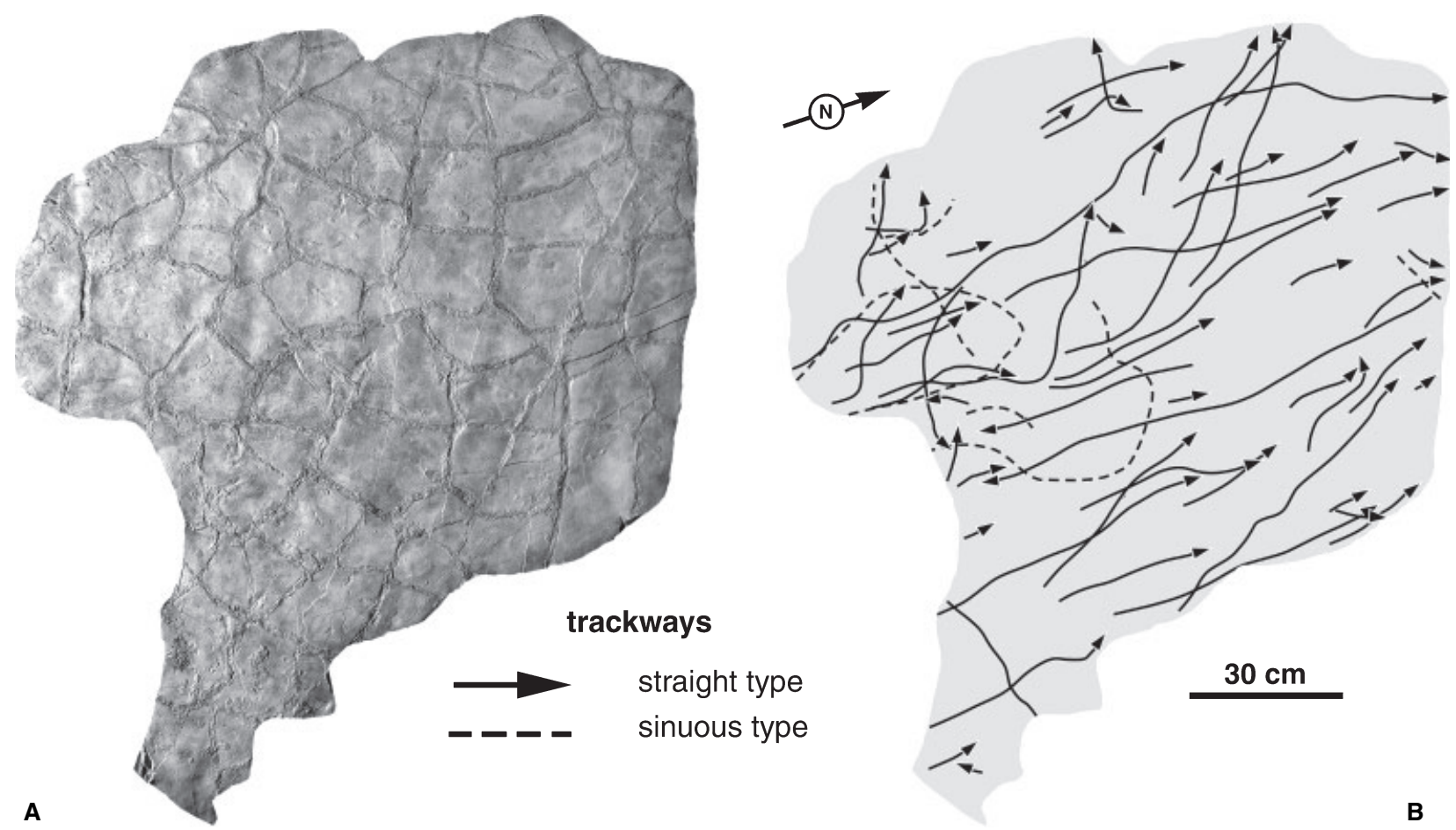

TEXT-FIG. 11. Numerical abundance and preferential orientation of Pterichnus isopodicus isp. nov. along Arthro 2 bed, same locality and age as in Text-fig. 4. A, resine replica from rock slab (FSL 525005) showing mudcrack network. B, trackway mapping from same slab with solid and dotted lines representing orientated (Types 1 and 2) and sinuous (Types 3 and 4) trackways, respectively (see text). 


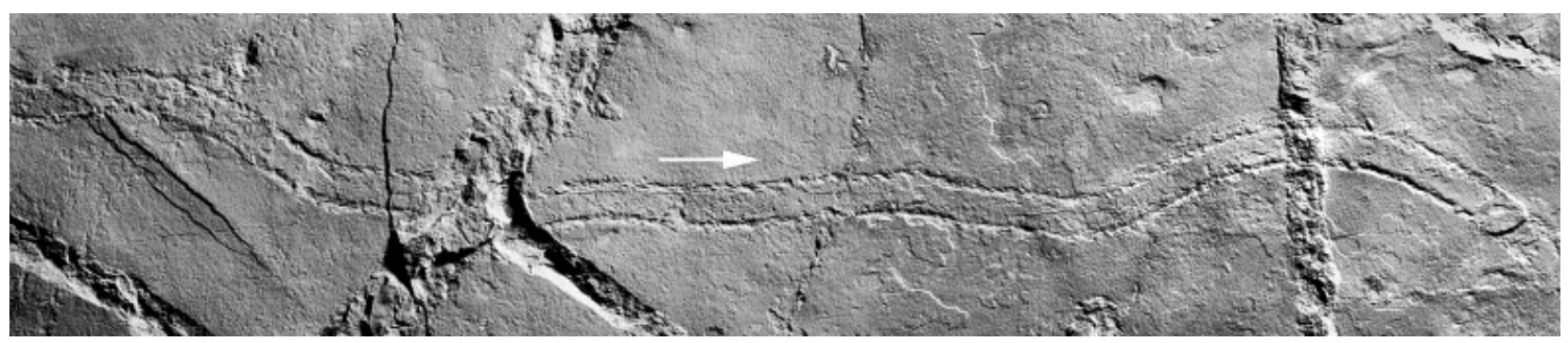

TEXT-FIG. 12. Pterichnus isopodicus isp. nov., long trackway interrupted at one end (either death mark or terminal animal burrow), Arthro 2 bed, Mas de Pégourdy quarry, field photograph; white arrow indicates the assumed direction of movement of the tracemaker; $\times 0 \cdot 5$.

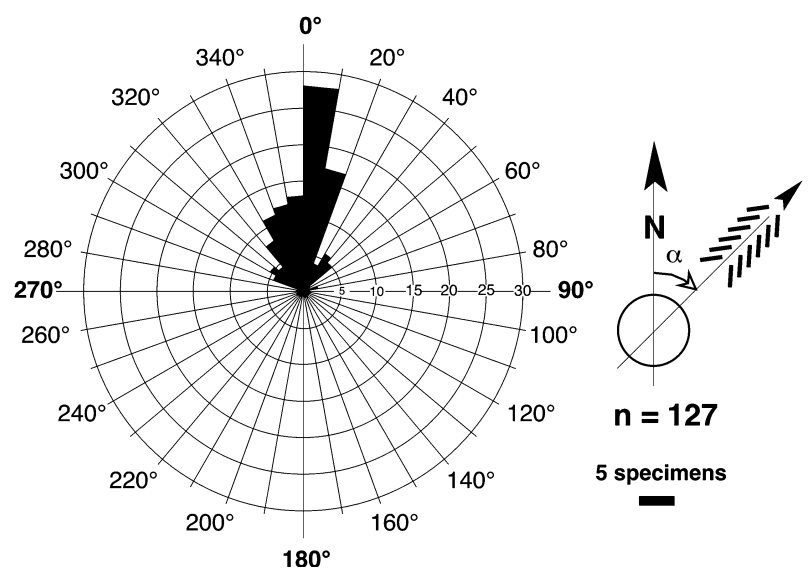

TEXT-FIG. 13. Orientation of 127 trackways from Arthro 2 bed.

straight trackways (Types 1 and 2) was measured both in the field and from resin replicas (Text-fig. 11). The direction of movement was inferred from experiments made in the laboratory using living isopods (e.g. Ligia; Margérard 2000). The chevron-like structures produced by crawling isopods during experiments point in the direction of movement of the animal. We consider that it was the same for the isopods of Crayssac. Our measurements clearly indicate a preferential orientation of trackways, which may be interpreted as the unidirectional migration of isopods (Text-fig. 13). A similar case of orientated trackways is described for Devonian arthropods (abundant, straight, subparallel trackways; Draganits et al. 2001). Such migratory behaviour may be triggered by the drying up of the habitat or predatory pressure, factors that may have forced the animals to seek refuge (Trewin and McNamara 1995; Draganits et al. 2001).

Tidal migrators? The tidally rhythmic behaviour of marine isopods is well documented (Naylor 1985). The link between onshore migrations and endogenous rhythmicity has been proposed for Eurydice pulchra (Jones and Naylor 1970) and Excirolana chiltoni (Enright 1972). For example,
Eurydice pulchra, common on sandy beaches, migrates over the intertidal zone during high tide. This isopod emerges from the sand during the flood tide, feeds actively during high tide and reburrows on the ebb (Salvat 1966; Jones and Naylor 1970; Fish and Fish 1972; Warman et al. 1991). It is active for about 5-6 h before it reburrows at approximately the same place from which it emerged (Jones and Naylor 1970). However, the sandy beaches where these observations were made are high-energy settings that differ markedly from the low-energy mudflats of Crayssac.

According to our measurements, the preferential direction of trackways is northwards (present-day orientation). This is in a direction perpendicular to that of most reptile trackways which co-occur with isopod traces in the Crayssac biota. It is reasonable to envisage that the reptiles, mainly dinosaurs and pterosaurs (Mazin et al. 1995, 1997) were walking (or hovering; pterosaurs) along the shoreline searching for food on tidal flats (e.g. marine invertebrates or strand-line carcasses). If this hypothesis is correct, then isopods would have migrated landwards or seawards perpendicular to the shoreline. This assumed polarity may reflect the natural behaviour of isopods, escaping either from desiccation (falling tide) or from flooded areas (flood tide). The numerical dominance of Types 1 and 2 trackways, i.e. those produced on a wet but not submerged substratum, seems to indicate that the activity of isopods chiefly took place in the intertidal area at a particular time in the desiccation process. The tidal rhythmicity and its cascade of environmental variations (e.g. humidity) are likely to have exerted a major control on the behaviour of the Crayssac isopods. To us, the most plausible interpretation is that the isopods lived under water at high tide and crawled back to the sea across exposed tidal flats at low tide (Text-fig. 14). Similar tidalinfluenced behaviour is known to occur in Recent sphaeromid isopods. Unusually long emersions may have favoured the abundance and concentration of trackways in contrast to shorter periods of emersion. This would explain the relative scarcity of Pterichnus beds at Crayssac 

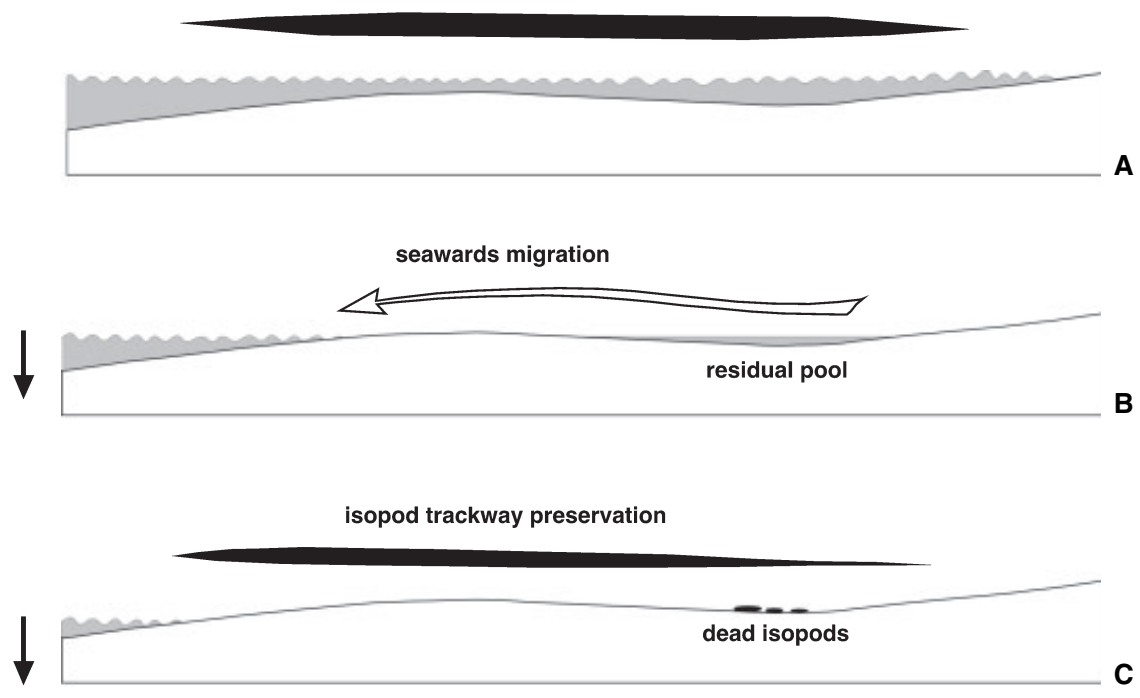

TEXT-FIG. 14. Explanation of the mode of trackway production and the preservation of trackways and isopods in the intertidal zone.

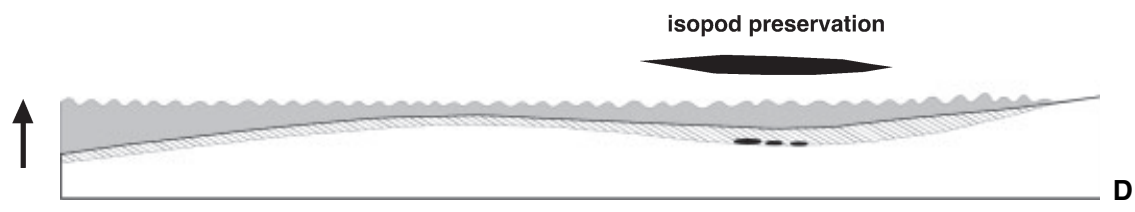

and their high density on the rare bedding planes where they are preserved.

\section{CONCLUSIONS}

Well-preserved criss-crossed networks of small trackways (Pterichnus isopodicus isp. nov.) are described from the Crayssac Lagerstätte (Tithonian) and attributed to a single species of isopod crustacean similar to Archaeoniscus. The different trackway morphotypes correspond to locomotory traces made within a range of substratum from wet (mud saturated with water) to almost dry. The most sinuous trackways seem to indicate a regular vagrant activity (pascichnia?) in wet conditions whereas the numerous straight trackways merely indicate rapid crawling on a firmer ground (repichnia). The possible migratory behaviour of isopods inferred from trackway-orientation may have been influenced by tidal rhythm. Unusually long emersions may have favoured the preservation of dense networks of trackways. Both high-density trackway networks and assemblages (body fossils) at Crayssac and coeval localities in similar environmental settings indicate that isopods were important colonizers of intertidal/supratidal environments in the Upper Jurassic.

Acknowledgements. Fieldwork at Crayssac was co-ordinated by the University of Poitiers (UMR 6046, CNRS) and the University of Lyon 1 (UMR 5125, CNRS). We are grateful to the numerous institutions, funding bodies and private companies for their financial support. We thank Drs S. J. Braddy, A. J. Ross and M. Williams for suggestions and improvements, Mr C. Gourrat and Mr G. Lafaurie for providing isopod specimens, Mr A. Prieur for technical assistance with fossil preparation and management of collections, and $\mathrm{Mr} \mathrm{N}$. Podevigne and Ms A. Armand for assistance with photography and drawing, respectively. This work is a contribution to our research programme (UMR 5125) on the 'Structure and functioning of palaeoecosystems'.

\section{REFERENCES}

AMMON, L. von 1882. Ein Beitrag zur Kenntniss der fossilen Asseln. Sitzungsberichte der Mathematisch-Physikalischen Classe der Königlichen Bayerischen Akademie der Wissenschaften, 1882, 507-551.

ANDERSON, A. M. 1981. The Umfolozia arthropod trackways in the Permian Dwyka and Ecca series of South Africa. Journal of Paleontology, 55, 84-108.

BANDEL, K. 1967. Isopod and limulid marks and trails in Tonganoxie Sandstone (Upper Pennsylvanian) of Kansas. Paleontological Contributions, University of Kansas, 19, 1-10.

_ and QUINZIO-SINN, L. A. 1999. Paleozoic trace fossil from the Cordillera Costal near Concepcion, connected to a review of the Paleozoic history of central Chile. Neues Jahrbuch für Geologie und Paläontologie, Abhandlungen, 211, 171-200.

BARTHEL, K. W., SWINBURNE, N. H. M. and CONWAY MORRIS, S. 1990. Solnhofen, a study in 
Mesozoic palaeontology. Cambridge University Press, Cambridge, $236 \mathrm{pp}$.

BIRKENMAJER, K. and BRUTON, D. L. 1971. Some trilobite resting and crawling traces. Lethaia, 4, 303-319.

BORNEMANN, J. G. 1889. Über den Buntsandstein in Deutschland und seine Bedeutung für die Trias. Beiträge Geologie, Paleontologie, 1, 1-61.

BRADDY, S. J. 1996. Palaeobiology of the Eurypterida. Unpublished $\mathrm{PhD}$ thesis, University of Manchester, $505 \mathrm{pp}$.

— 2001. Trackways - Arthropod locomotion. 389-393. In BRIGGS, D. E. G. and CROWTHER, P. R. (eds). Palaeobiology II. Blackwell, Oxford, 583 pp.

BRADY, L. F. 1947. Invertebrate tracks from Coconino Sandstone of northern Arizona. Journal of Paleontology, 21, 466472.

— 1949. Oniscoidichnus, new name for Isopodichnus Brady 1947 not Bornemann 1889. Journal of Paleontology, 23, 573.

BRANDT, A., CRAME, J. A., POLZ, H. and THOMSON, M. R. A. 1999. Late Jurassic Tethyan ancestry of Recent southern high-latitude marine isopods (Crustacea, Malacostraca). Palaeontology, 42, 663-675.

BRIGGS, D. E. G. and ALMOND, J. E. 1994. The arthropleurids from the Stephanian (Late Carboniferous) of Montceaules-Mines (Massif Central - France). 127-135. In POPLIN, C. and HEYLER, D. (eds). Quand le Massif Central etait sous l'Equateur, un ecosystème carbonifere a Montceau-les-Mines. CTHS, Paris, 328 pp.

- ROLFE, W. D. I. and BRANNAN, J. 1979. A giant myriapod trail from the Namurian of Arran, Scotland. Palaeontology, 22, 273-291.

CASTER, K. 1944. Limuloid trails from the Upper Triassic (Chinle) of the Petrified Forest National Monument, Arizona. American Journal of Science, 242, 74-84.

COURTINAT, B., HANTZPERGUE, P., RiO, M. and MAZIN, M. 2003. Matière organique sédimentaire et paléoenvironnements du Tithonien inférieur quercynois. Geobios, 36, 13-25.

CRIMES, T. P. 1970. The significance of trace fossils in sedimentology, stratigraphy and palaeoecology with examples from Lower Palaeozoic strata. 101-126. In CRIMES, T. P. and HARPER, J. C. (eds). Trace fossils. Geological Journal, Special Issue, 3, 547 pp.

CUBAYNeS, R., FAURÉ, P., HANTZPERGUE, P., PELISSIER, T. and REY, J. 1989. Le Jurassique du Quercy: unités lithostratigraphiques, stratigraphie et organisation séquentielle, évolution sédimentaire. Géologie de la France, 3, 33-62.

DAWSON, J. W. 1873. Impressions and footprints of aquatic animals and imitative markings on Carboniferous rocks. American Journal of Science, Series 3, 5, 16-24.

DELFAUD, J. 1969. Essai sur la géologie dynamique du domaine aquitano-pyrénées durant le Jurassique et le Crétacé inférieur. Thèse de Doctorat d'Etat, Université de Bordeaux, 5 vols, $857 \mathrm{pp}$.

DRAGANITS, E., BRADDY, S. J. and BRIGGS, D. E. G. 2001. A Gondwanan coastal arthropod ichnofauna from the Muth Formation (Lower Devonian, northern India): paleoenvironment and tracemaker behaviour. Palaios, 16, 126-147.
ENRIGHT, J. T. 1972. A virtuoso isopod: circa-lunar rhythms and their tidal fine structure. Journal of Comparative Physiology, 77, 141-162.

FELDMANN, R. M., VEGA, F. J., APPLEGATE, S. P. and BISHOP, G. A. 1998. Early Cretaceous arthropods from the Tlayua Formation at Tepexi de Rodriguez, Puebla, Mexico. Journal of Paleontology, 72, 79-90.

FISH, J. D. and FISH, S. 1972. The swimming rhythm of Eurydice pulchra Leach and a possible explanation of intertidal migration. Journal of Experimental Marine Biology and Ecology, 8, 195-200.

FORTEY, R. A. and SEILACHER, A. 1997. The trace fossil Cruziana semiplicata and the trilobite that made it. Lethaia, 30, 105-112.

FRICKHINGER, K. A. 1994. The fossils of Solnhofen. Goldschneck, Korb, 336 pp.

GAILLARD, C., BERNIER, P., BARALE, G., BOURSEAU, J. P., DE LAPPARENT DE BROIN, F., BUfFETAUT, E., EZQUERRA, R., GALL, J. C., RENOUS, S. and WENZ, S. 2003. A giant Upper Jurassic turtle revealed by its trackways. Lethaia, 36, 315-322.

GALL, J. C., BERNIER, P., GAILLARD, C., BARALE, G., BOURSEAU, J. P., BUfFETAUT, E. and WENZ, S. 1985. Influence du développement d'un voile algaire sur la sédimentation et la taphonomie des calcaires lithographiques. Exemple du gisement de Cerin (Kimméridgien supérieur, Jura méridional français). Comptes Rendus de l'Académie des Sciences, Paris, 301, 547-552.

GEVERS, T. W., FRAKES, L. A., EDWARDS, L. N. and MARZOLF, J. E. 1971. Trace fossils in the Lower Beacon sediments (Devonian), Darwin Mountains, South Victoria land, Antarctica. Journal of Paleontology, 45, 81-94.

GILMORE, C. W. 1926. Fossil footprints from the Grand Canyon. Smithsonian Miscellaneous Collections, 77, 1-41.

GOLDRING, R. 1985. The formation of the trace fossil Cruziana. Geological Magazine, 122, 65-72.

- and SEILACHER, A. 1971. Limulid undertracks and their sedimentological implications. Neues Jahrbuch für Geologie und Paläontologie, Abhandlungen, 137, 422-442.

GORDON, E. A. 1988. Body and trace fossils from the Middle-Upper Devonian Catskill magnafacies, southeastern New York, USA. 139-156. In McMILLAN, N. J., EMBRY, A. F. and GLASS, D. J. (eds). The Devonian of the world. Canadian Society of Petroleum Geologists, Memoir, 14 (2), 674 pp.

GUTHÖRL, P. 1934. Die Arthropoden aus dem Carbon und Perm des Saar-Hahe-Pfalz-Gebietes. Jahrbuch der Königlisch Preussischen Geologischen Landesanstalt zu Berlin, Neue Folge, 164, 1-219.

HAACK, W. 1918. Über einen Isopoden aus dem Serpulit des westlichen Osnings. Jahrbuch der Königlisch Preussischen Geologischen Landesanstalt zu Berlin, Neue Folge, 39, 73-102.

HANTZPERGUE, P. and LAFAURIE, G. 1994. Les calcaires lithographiques du Tithonien quercynois. In BERNIER, P. and GAILLARD, C. (eds). Les calcaires lithographiques, sédimentologie, paléontologie, taphonomie. Geobios, MS 16, 237-243.

HÄNTZSCHEL, W. 1975. Trace fossils and problematica. W1-W269. In MOORE, R. C. and TEICHERT, C. (eds). 
Treatise on invertebrate paleontology. Part W. Miscellanea. Geological Society of America, Boulder and University of Kansas Press, Lawrence, 269 pp.

HITCHCOCK, E. 1858. Ichnology of New England. A report on the sandstone of the Connecticut Valley, especially its footprints. W. White, Boston, $220 \mathrm{pp}$.

1865. Supplement of the ichnology of New England. Wright \& Porter, Boston, 96 pp.

JOHNSON, E. W., BRIGGS, D. E. G., SUTHREN, R. J., WRIGHT, J. L. and TUNNICLIFF, S. P. 1994. Non-marine arthropod traces from the subaerial Ordovician Borrowdale Volcanic Group, English Lake District. Geological Magazine, 131, 395-406.

JONES, D. A. and NAYLOR, E. 1970. The swimming rhythm of the sand beach isopod Eurydice pulchra. Journal of Experimental Marine Biology and Ecology, 4, 188-199.

MANGÁNO, M. G., BUATOIS, L. A., WEST, R. R. and MAPLES, C. G. 2002. Ichnology of a Pennsylvanian equatorial tidal flat - the Stull Shale Member at Waverley, eastern Kansas. Kansas Geological Survey, Bulletin, 245, 1-133.

MARGÉRARD, A. L. 2000. L'isopode Archaeoniscus (Crustacea) du Jurassique supérieur 0.-européen (France, GrandeBretagne): anatomie, ichnologie, modélisation biomécanique. Mémoire de Diplôme d'Études Approfondies PalSed, Université de Lyon-1, unpublished.

MARTINSSON, A. 1970. Toponomy of trace fossils. 323-330. In CRIMES, T. P. and HARPER, J. C. (eds). Trace fossils. Geological Journal, Special Issue, 3, 547 pp.

MAZIN, J. M., BILLON-BRUYAT, J. P., HANTZPERGUE, P. and LAFAURIE, G. 2003. Ichnological evidence for quadrupedal locomotion of pterodactyloid pterosaurs: the trackways from the Late Jurassic of Crayssac (southwestern France). 283-313. In BUFFETAUT, E. and MAZIN, J. M. (eds). Evolution and palaeobiology of pterosaurs. Geological Society, London, Special Publication, 217, $347 \mathrm{pp}$.

- HANTZPERGUE, P., BASSOUlet, J. P., LAFAURIE, G. and VIGNAUD, P. 1997. Le gisement de Crayssac (Tithonien inférieur, Quercy, Lot, France): découverte de pistes de dinosaures en place et premier bilan ichnologique. Comptes Rendus de l'Académie des Sciences, Paris, 325, 733739.

LAFAURIE, G. and VIGNAUD, P. 1995. Des pistes de ptérosaures dans le Tithonien de Crayssac (Quercy, Lot). Comptes Rendus de l'Académie des Sciences, Paris, 321, 417-424.

MILNE-EDWARDS, M. H. 1843. Notes sur deux Crustacés fossiles de l'Ordre des Isopodes. Annales des Sciences Naturelles, Serie 2, 20, 326-329.

MÜNSTER, G. 1840. Ueber einige Isopoden in den Kalkschiefern von Bayern. Beiträge zur Petrefactenkunde (Bayreuth), 3, $19-23$.

— 1842. Beschreibung drei neuer Arten Crustaciten. Beiträge zur Petrefactenkunde (Bayreuth), 5, 76-78.

NAYLOR, E. 1985. Tidally rhythmic behaviour of marine animals. Symposia of the Society for Experimental Biology, 39, 6393.

NIELSEN, E. 1949. On some trails from the Triassic beds of East Greenland. Meddelelser om Grønland, 149, 1-44.
POLLARD, J. E. 1985. Isopodichnus, related arthropod trace fossils and notostracans from Triassic fluvial sediments. Transactions of the Royal Society of Edinburgh, Earth Sciences, 76, 273-285.

_ and WALKER, E. F. 1984. Reassessment of sediments and trace fossils from Old Red Sandstone (Lower Devonian) of Dunure, Scotland, described by John Smith (1909). Geobios, 17, 567-576.

POLZ, H. 1998. Schweglerella strobli gen. nov., sp. nov. (Crustacea: Isopoda: Sphaeromatidae), eine Meeres-Assel aus den Solnhofener Plattenkalken. Archaeopteryx, 16, 19-28.

ROMAN, M. L. and DALENS, H. 1999. Ordre des Isopodes (Epicarides exclus) (Isopoda Latreille, 1817). Mémoires de l'Institut Océanographique de Monaco, 19, 177-278.

ROSS, A. J. and VANNIER, J. 2002. Crustacea (excluding Ostracoda) and Chelicerata of the Purbeck Limestone Group, southern England: a review. Special Papers in Palaeontology, 68, 71-82.

SADLER, C. J. 1993. Arthropod trace fossils from the Permian De Chelly Sandstone, northeastern Arizona. Journal of Paleontology, 67, 240-249.

SALVAT, B. 1966. Eurydice pulchra Leach (1815) Eurydice affinis (Hansen 1905) Isopodes Cirolanidae, taxonomie, éthologie, écologie, répartition verticale et cycle reproducteur. Actes de la Société Linnéenne de Bordeaux, A, 103, $1-77$.

SCHINDEWOLF, O. 1928. Studien aus dem Marburger Buntsandstein. IV. Isopodichnus problematicus (Schindwf) im Unteren und Mittleren Buntsandstein. Senckenbergiana, 10, 27-37.

SCHWEIGERT, G. 1993. Die Ammonitengattungen Gravesia Salfeld und Tolvericeras Hantzpergue und ihre Bedeutung für den Grenzbereich Oberkimmeridgium/Untertithonium im Schwäbischen Jura. Geologische Blatter für Nordost-Bayern (Erlangen), 43, 167-186.

SEILACHER, A. 1953. Studien zur Palichnologie, 1. Über die Methode der Palichnologie. Neues Jahrbuch für Geologie und Paläontologie, Abhandlungen, 93, 421-452.

— 1955. Spuren und Lebensweise des Trilobiten. In SCHINDEWOLF, O. H. and SEILACHER, A. (eds). Beiträge zur Kenntnis des Kambriums in der Salt Range (Pakistan). Abhandlungen der Mathematisch-Naturwissenschaftlichen Klasse, 10, 86-116.

- 1970. Cruziana stratigraphy of 'nonfossiliferous' Paleozoic sandstones. 447-476. In CRIMES, T. P. and HARPER, J. C. (eds). Trace fossils. Geological Journal, Special Issue, 3, 547 pp.

SMITH, J. 1909. Upland fauna of the Old Red Sandstone Formation of Carrick, Ayrshire. Cross, Kilwinning, 60 pp.

STRAELEN, V. vAN 1928. Contribution à l'étude des isopodes méso- et cénozoïques. Mémoires de l'Académie Royale de Belgique, 9, 1-68.

THIERRY, J. and BARRIER, E. 2000. Early Tithonian (141139 Ma). In DERCOURT, J., GAETANI, M., VRIELYNCK, B., BARRIER, E., BIJU-DUVAL, B., BRUNET, M. F., CADET, J. P., CRASQUIN, S. and SANDULESCU, M. (eds). Peri-Tethys palaeogeographical atlas. Commission for the Geologic Map of the World, Paris, Map 10. 
TREWIN, N. H. 1976. Isopodichnus in a trace fossil assemblage from the Old Red Sandstone. Lethaia, 9, 29-37.

1994. A draft system for the identification and description of arthropod trackways. Palaeontology, 37, 811-823.

and McNAMARA, K. J. 1995. Arthropods invade the land: trace fossils and palaeoenvironments of the Tumblagooda Sandstone (?late Silurian) of Kalbarri, Western Australia. Transactions of the Royal Society of Edinburgh, Earth Sciences, 85, 177-210.

WALKER, E. F. 1985. Arthropod ichnofauna of the Old Red Sandstone at Dunure and Montrose, Scotland. Transactions of the Royal Society of Edinburgh, Earth Sciences, 76, 287-297.

WALTER, H. 1983. Zur Taxonomie, Ökologie und Biostratigraphie der Ichnia limnish-terrestrischer Arthropoden des mitteleuropäische Jungpaläozoikums. Freiberger Forschungshefte, C, 382, 146-193.

WARMAN, C. G., O'HARE, T. J. and NAYLOR, E. 1991. Vertical swimming in wave-induced currents as a control mechanism by a sand-beach isopod. Marine Biology, 111, $49-50$.

WEBER, B. and BRADDY, S. J. 2004. A marginal marine ichnofauna from the Blaiklock Glacier Group (?Lower Ordovician) of the Shackleton Range, Antarctica. Transactions of the Royal Society of Edinburgh, Earth Sciences, 94, $1-20$.

WIEDER, R. W. and FELDMANN, R. M. 1992. Mesozoic and Cenozoic fossil isopods of North America. Journal of Paleontology, 66, 958-972. 